\title{
The Influence of Sex Appeal on Consumers Attitude toward the Ads Moderated by Product Factors
}

\author{
Aji Cahya Nusantara ${ }^{1}$, Budhi Haryanto ${ }^{2} \bowtie$ \\ Faculty of Economics and Business, Universitas Sebelas Maret, Surakarta, Indonesia ${ }^{1,2}$
}

\begin{tabular}{l} 
Info Article \\
\hline History Article: \\
Received 14 July 2018 \\
Approved 7 September 2018 \\
Published September 2018 \\
\hline Keywords: \\
Sex Appeal; Product Factors; At- \\
titude towards the Ads; Consumer \\
Behavior. \\
\hline
\end{tabular}

History Article:

Received 14 July 2018

Published September 2018

Sex Appeal; Product Factors; At Behavior.

\begin{abstract}
This study wants to examine the relationship between sex appeal and attitude towards the ads, and more than, this study also wants to examine the role of product factors in moderating the relationship of this two variables. Experimental design is done to control the relation among the variables observed in this study. The participants consist of 100 males' undergraduate students of Faculty of Economics and Business, Universitas Sebelas Maret, Surakarta-Indonesia, who are divided into 4 groups. Generalized Auto Regression Conditional Hetero-regressive (GARCH) is statistical method chosen to analysis the data. The results showed that sex appeal is an effective stimulus affects the individual positive attitude toward an advertisement. As well as product factor is another stimulus, which effectively influence positive attitudes toward advertising. But in this study also found that the product factor is not moderate the relationship between sex appeal and positive attitude toward advertising. In addition to this study also discusses the implications of both theoretical and practical, as well as the limitations of the study.
\end{abstract}

\section{Pengaruh Daya Tarik Seksual pada Sikap Konsumen terhadap Iklan yang di Moderasi oleh Faktor Produk}

\begin{abstract}
Abstrak
Penelitian ini ingin menguji hubungan antara daya tarik seks dan sikap terhadap iklan, selain itu penelitian ini juga ingin menguji peran faktor produk dalam memoderasi hubungan kedua variabel tersebut. Desain eksperimental dilakukan untuk mengontrol hubungan antara variabel yang diamati dalam penelitian ini. Para peserta terdiri dari 100 mahasiswa sarjana yang berjenis kelamin pria, dari Fakultas Ekonomi dan Bisnis, Universitas Sebelas Maret, Surakarta, yang dibagi menjadi 4 kelompok. General Auto Regression Conditional Hetero-regresif (GARCH) adalah metode statistik yang dipilih untuk menganalisis data. Hasil pengujian mengindikasikan bahwa daya tarik seks merupakan stimulus efektif mempengaruhi sikap positif individu terhadap iklan. Serta faktor produk adalah stimulus lain, yang secara efektif mempengaruhi sikap positif terhadap periklanan. Namun dalam penelitian ini juga ditemukan bahwa faktor produk tidak memoderasi hubungan antara daya tarik seks dan sikap positif terhadap iklan. Selain itu penelitian ini juga membahas implikasi baik secara teoritis maupun praktis, serta keterbatasan penelitian.
\end{abstract}

JEL Classification: M3, M31

How to Cite: Nusantara, A. C., \& Haryanto, B. (2018). The Influence of Sex Appeal on Consumers Attitude toward the Ads Moderated by Product Factors. Jurnal Dinamika Manajemen, 9(2), 250-258. 
Aji Cahya Nusantara \& Budhi Haryanto/ The Influence of Sex Appeal on Consumers Attitude ...

\section{INTRODUCTION}

The use of sexual appeal, provocative sexual appeal and eroticism in advertising is very common, which has increased in recent years (Soley \& Kurzbard, 1986: Lambiace et al., 1999; Duncan, 2002; Haryanto et al., 2015). Advertising campaign for Dior, Calvin Klein, or Yves Saint Laurent often uses advertising that contained sexy images. This 'porno chic' is very popular in both the luxury and fragrance business (Barnier \& Florance, 2006). The use of sex appeal in advertising holds the numbers of potential advantage if it is used appropriately (Courtney \& Whippley, 1983).

The objective of this study is to build consumer's buying intention model which focuses on sex appeal advertising in order to attract attention more easily (Reid \& Soley, 1983). Anabila et al. (2015) conceptualized sex as the strongest appeal in behavioral aspect. In past study explained that sex appeal could influence a person in making decision of purchasing a product. Therefore, this statement may help marketers to work less hard because sex appealing ad has better recognition in consumer's mind. This study wants to explain the process of consumer intention on buying product that influenced by sex appeal. Consumer buying intention in this context means cognitive process that stays on attitude aspect. Through the models constructed, this research is able to give insight to marketers in order to construct a strategy. It related with how to increase the intention of buying through sex appeal which is moderated by product factor with consideration of product factor as external condition.

There are three variables used in this research. There are sex appeal, product factor, and attitude towards the ads. They were adopted from previous studies (Dudley, 1999; Sengupta \& Dahl, 2008; Black et al., 2010). Sex appeal conceptualized as the independent variable in this study. Sex appeal is defined in a broad sense as messages, whether as brand information in advertising context or as persuasive appeal in marketing contexts, which are associated to sexual information (Reichert et al., 2001). Sex appeal in particular case is associated with nudity, which is sex that usually operationalized as nudity that referred to as amount of style of clothing worn and level of undress (Reichert \& Ramirez, 2000). Nudity means displaying of skin that normally covered (Sugiarto, 2013).

As dependent variable, attitude is defined as a learned predisposition to respond in a consistently favorable or unfavorable manner with respect to a given object (Fishbein \& Ajzen, 1975) and it refers to positive or negative feeling directed at some object (Lutz, 1991). Study shown that sexual appealing ad generate a positive attitude towards the ad more than the non-sexual ad (Reichert et al., 2001). Therefore, advertising with sexual content generated higher level purchase intention than those with non-sexual content (Dudley, 1999; Lull \& Bushman, 2015).

Previous studies had conceptualized into several different constructs, including attitudes towards advertising (LaTour, 1994; Dudley, 1999; Liu \& Cheng, 2006; Jones 2009; Visetbhakdi, 2010; Black et al., 2010) attitudes toward brands (LaTour, 1994; Dudley, 1999; Liu \& Cheng, 2006; Black et al., 2010; Visetbhakdi, 2010), consumer attitudes (Sengupta, 2008), buying intentions (LaTour, 1994; Jones, 2009; Visetbhakdi, 2010; Lull \& Bushman, 2015), attitudes toward companies (Dudley, 1999), dimensions of moral philosophical ethics (LaTour, 1994).

In this study, attitudes toward advertising were the variables that were the objectives of the study, because in the consumer behavior process in purchasing a brand, purchase intention was influenced by attitudes toward the brand and attitude towards the ad. Previous studies have revealed that these two variables have a significant and positive relationship (Visetbhakdi, 2010; Lull \& Bushman, 2015). That is, the higher the positive attitude towards advertising, the higher the positive attitude towards the brand, which in turn will shape the purchase intention of the brand. In this initial step, this study focused on attitudes toward advertising, 
because by explaining the effective predictor of the variable, it can in turn affect attitudes toward the brand and purchase intention towards the brand.

Related to the predictors of attitudes toward advertising, previous studies indicated diversity of these variables, including several researchers who conceptualized the types of sexual advertising to predict attitudes (LaTour, 1994; Dudley, 1999; Liu \& Cheng, 2006; Jones \& Reid, 2009; Visetbhakdi , 2010; Black et al., 2010) there are even some who predict attitudes through gender (Liu \& Cheng, 2006; Sengupta, 2008; Black et al., 2010) and while some predict attitudes through personality traits (Black et al., 2010). This study conceptualizes sex appeal as a stimulus for attitudes toward advertising. This means that attitudes toward advertising are influenced by the degree of sex appeal from the advertising star who is the endorser.

\section{Hypothesis Development \\ Relationship between Advertising and Sex Ap- peal}

According to Reichert (2001) sex appeal is defined as message, whether as brand information in marketing context or as persuasive appeal in marketing context which are associated with sexual information. Therefore, sex appeal serves a number of crucial roles in advertising including attracting attention (Reid \& Soley, 1983), enhancing recall (Steadman, 1969), evoking emotional responses (Courtney \& Whipple, 1983) and increasing persuasion (LaTour et al., 1990; Saunders, 1996) as well as buying intention (Lull and Bushman, 2015). The use of sexual appeal in advertising has been increasing in Western countries and becoming more overt as advertising attempt to find a particular approach to break the media clutter (LaTour \& Henthorne, 1994).

Previous studies have indicated a significant and positive relationship between sex appeal in advertising and attitudes toward advertising (LaTour, 1994; Dudley, 1999; Liu \& Cheng, 2006; Jones, 2010; Visetbhakdi, 2010). This means that at a high sex appeal level it will result in attitudes towards advertising that are higher than the low sex appeal level. Thus the following hypothesis is proposed:

$\mathrm{H} 1$ : Advertising containing sex appeal will report more favorable attitude towards the ad, than the advertising not containing sex appeal.

\section{Relationship between Advertising and Product Factors}

In this study, product factors were conceptualized as moderating variables of the relationship between sex appeal and attitudes toward advertising. Previous studies indicate that in behavioral contexts, the relevance between the type of product advertised and sex appeal becomes a determining variable in sex appeal and attitudes toward advertising (Assael, 2004; Lee et al., 2017). Another study explains that product relevance or congruence is also an important factor in influencing viewers' responses to advertisements that display sex appeal (Peterson \& Kerin, 1977). Products can be classified as relevant to sexual attraction if there is a connection between sexual appearance and perception according to the product being advertised (LaTour et al., 1990; Malik, 2016). Previous research has shown that products that have relevance to high sex appeal ads have a higher advertising attitude than products that have low relevance (Black et al., 2010).

Furthermore, previous studies have suggested that product factor is an important in viewers' responses to sexual appeal (Peterson \& Kerin, 1997). Product can be classified as relevant to sexual appeal if the hold pre-existing sexual connotation and irrelevant if there these connotations are lacking (LaTour, 1990). Female is more effective for advertising body oil, perfumes, and soap rather than ratchet set. The product has to be relevant with the female model to generate positive attitude. The message of the advertisement can be accepting with the viewers. The relationship between product factor and nudity is now generally accepted. It has been included in many studies of sexual appeal in advertising (LaTour, 1990; LaTour \& Hent- 
Aji Cahya Nusantara \& Budhi Haryanto/ The Influence of Sex Appeal on Consumers Attitude ...

horne, 1994). Black et al. (2010) says that advertising with product relevancy generates positive attitude toward the ad than the irrelevant product advertising.

According to Assael (2004), consumer attitude can be influenced by a number of variables which are both internal and external. In this study, product factor is an external variable that can influence consumer's attitude. Hence, the following hypothesis is:

$\mathrm{H} 2$ : Advertisement using sexual appeal will report more favorable attitude towards the ads when the advertisement features a relevant product, than when the ads feature irrelevant product.

\section{METHOD}

The analysis was carried out by experimental design, which allowed the researcher to do some manipulation of the independent variables, to explain the effect on the observed dependent variable (Campbell \& Stanley, 1966). The purpose of this experimental design in this study is to examine the role of sexual appeal towards consumer attitude towards the ad, which was moderated by product factor. This is then used as a basis for consideration for making a marketing strategy (Montgomery, 2001)

In this study there were two manipulated variables, namely sex appeal and product factor. Factorial design was used to form experimental design groups, namely two (sex appeal: Most appealing vs Least appealing) $\mathrm{x}$ two (product factor: relevant vs irrelevant), so that in this study there were four experimental (Table 1). In this study involved 100 individuals as participants, so that each group had 25 individuals. This number of participants is determined by considering the adequacy of the data to be analyzed using GARCH analysis, in addition to aspects of time limitations and research funding.

Related to the materials, sex appeal has lots of items such as level of nudity, ability to giving pleasure, command attention, energize and arouse. This study used sexiness to represent the different degree of sex appeal. In other word, the model featuring a low level of sex appeal in the ads showing less curves on their body than those featuring a high degree of sex appeal in the ads. Perfume was selected as relevant product and pencil eraser was selected for the irrelevant product. Both products were selected because perfume and pencil eraser are commonly used by college student.

On the first stimuli, the most appealing model featuring product which is relevant represents high degree of sex appeal with relevant product. On the second stimuli, the most appealing model featuring irrelevant product represents high degree of sex appeal with irrelevant product. On the third stimuli, showing the least appealing model with relevant product represents low degree of sex appeal with relevant product and the forth stimuli is least appealing model poses with irrelevant product represents low degree of sex appeal with irrelevant product.

Manipulation check is the next step that aims to test the effectiveness of stimulus material. High sex appeal is described by the image

Table 1. Number of Participants of each group

\begin{tabular}{ccc}
\hline Experimental Group & Sex appeal - Product Factor & Number of Participants \\
\hline 1 & Most appealing-Relevant & 25 individuals \\
2 & Most appealing-Irrelevant & 25 individuals \\
3 & Least appealing-Relevant & 25 individuals \\
4 & Least appealing-Irrelevant & 25 individuals \\
\hline & Total & 100 individuals \\
\hline
\end{tabular}


of a woman who displays a high level of nakedness that shows beauty, sexiness, excitement of her body. On the contrary, the low sex appeal is described by the opposite image, which is a rather closed garment. Furthermore, the factor products in question are congruence between product and sex appeal, so perfume is chosen to describe high factor product congruence, while flash disks are chosen to describe low factor product congruence.

Before the experiment was carried out, all the stimulus materials made were tested for differences. This is done to explain the effectiveness of the stimulus material. Stimulus material is said to be effective if the material designed by the designed stimulus is perceived equally between the researcher and the participant. Each of the five items asked is (1) for sex appeal: the ability to awaken, the ability to energize, the ability to command attention, the level of sexiness and the ability to give pleasure; (2) product factors: similar, have connections, are suitable, congruent and identical.

The t-test analysis is a statistical technique used to test the differences in two paired samples (Tabachnick and Fidell, 1997). The results indicate that the image of women in closed and open clothing is perceived to have a sex appeal that is significantly different, so also between perfumes and flash disks are two perceived products that have different congruence (Table 2).

Table 2. Result of Manipulation Check

\begin{tabular}{ccccc}
\hline Variable & $\begin{array}{c}\text { Number } \\
\text { of item }\end{array}$ & Mean & Sig. \\
\hline Sex Appeal High & 5 & 4.2000 & \\
& & & .000 \\
Sex Appeal Low & 5 & 1.9000 & \\
\hline Product Factor High & 5 & 3.6250 & \\
& & & .000 \\
Product Factor Low & 5 & 1.6000 & \\
\hline
\end{tabular}

The participants for this experimental study were male S1 100 students at Universitas Sebelas Maret, Surakarta-Indonesia. The use of students in this study is to explain the real beha- vioral process in assessing an advertisement of a product through the cognitive process of students in assessing an advertisement of a product (Elliott et al., 1995; Black et al., 2010). The total numbers of participants for this study is 100 students. Of the participants studied, the majority were between 21 years- 22 years $(58 \%)$, the next were 18 years-20 years (34\%) and the rest were aged 24 years and above ( $8 \%)$.

While based on the study force, those who sit in semester 7-8 are as big as dominating this study (37\%), next are those who sit in semester 5-6 as second place (34\%), followed by those who sit in semester 3-4 (16\%), semester 1-2 (9\%), and finally those who sit in semester 9 and above (4\%). Based on family background, participants came from families with business backgrounds (35\%), then civil servants (26\%), private employees (17\%), retirees and farmers (16\%), and finaly the armed forces and police (6\%).

Based on the allowance received per month, the dominating is the participant with an allowance of less than 500,000 IDR (40\%), the next is with an allowance of 500,000 IDR$1,000,000$ IDR per month (27\%), then more than 2,000,000 IDR (20\%) and the rest is with an allowance of 1,000,000 IDR-2,000,000 IDR per month (13\%). While the participant status, they said they lived in the parents' house (71\%), the others stayed in the rented room (25\%), while the rest stayed with you (4\%).

In this study, the scenario developed is to make a blind experiment that is creating a condition such as the real conditions in advertising a product, so that participants are carried away in the atmosphere of a real product offer. The way in which a sales person entered was in the experimental room to introduce the product and distribute advertising brochures that contained experimental material according to the experimental group. Then participants responded to the stimulus material by filling out the questionnaire that was distributed. Closing process is done by giving an explanation that what has been done before is an experiment so that the product does not circulate in the market. 
Aji Cahya Nusantara \& Budhi Haryanto/ The Influence of Sex Appeal on Consumers Attitude ...

The following is a measurement of the variables developed. Sex appealing is broad sense as messages, whether as brand information in advertising context or as persuasive appeal in marketing contexts, which are associated to sexual information (Reichert et al., 2001). The items are: (1) ability of sexual appealing to arouse; (2) ability of sexual appealing to energize; (3) ability to command attention; (4) level of sexiness; (5) ability to giving pleasure. Product factor is used to highlight the different attitude generated by the use of nudity that has degree of relevancy with product associated with advertising. The items are: (1) similar; (2) fit; (3) congruency; (4) identical. Attitude toward the advertisement (Aad) is defined as "a predisposition to respond in a favorable or unfavorable manner to a particular advertising stimulus during a particular exposure occasion.

All of that indicators is measured by $\mathrm{Li}$ kert scale that range from $1=$ strongly disagree until $5=$ strongly agree. The items are: (1) feeling about the advertising; (2) enthusiastic; (3) like; (4) delighted; (5) positive responds.

In this study, to test the hypothesis developed Hierarchical Regression analysis (Sekaran, 2013). There are two equations that have been formulated to test the hypothesis. The first equation is to explain the main effects, namely the influence of sex appeal, product factors on attitudes toward advertising, and the second equation is to explain besides the main effect also to explain the moderating effect that is the influence of sex appeal products on attitudes toward advertising.

\section{RESULT AND DISCUSSION}

In this study, $\mathrm{ARCH} / \mathrm{GARCH}$ regression analysis is used to examine the effect of sex appeal on consumer attitude towards the ads and the moderating effect. This specific regression analysis is to accommodate variances that allegedly have heteroscedasticity problems. It means, variant from one space could affect the variance of another space. This phenomenon mostly occurred when there is fluctuating situation emerges, which can lead to changes in consumer's attitude.

The Relationship of sex appeal and consumers attitude towards the ads. The independent variable has two dimensions, which were sex appeal high and sex appeal low. This analytical tool is used to explain whether the two stimuli will lead to different attitude.

Table 3. Result of the Regression Analysis

\begin{tabular}{lcc}
\hline & Step 1 & \multicolumn{1}{c}{ Step 2 } \\
\hline Variable & $\begin{array}{c}\text { Estimate } \\
(\text { St.Error })\end{array}$ & $\begin{array}{c}\text { Estimate } \\
(\text { St. Error })\end{array}$ \\
\hline \multirow{2}{*}{ GARCH } & -.1134 & -2.4715 \\
& $(-1.552)$ & $(-.2604)$ \\
Constant & $1.5074^{* *}$ & 2.682 \\
& $(2.3811)$ & $(.2954)$
\end{tabular}

Main Effect

\begin{tabular}{lcc} 
Sex Appeal & $\begin{array}{c}.5006^{* * *} \\
(7.9668)\end{array}$ & $\begin{array}{c}.3583^{* *} \\
(3.0730)\end{array}$ \\
Product Factor & $.4173^{* * *}$ & $.4579^{*}$ \\
& $(6.7688)$ & $(1.8175)$ \\
Interaction effect & & \\
Sex appeal ${ }^{*}$ product & & .0016 \\
factor & & $(.1388)$ \\
R-Squared & .7831 & .7895 \\
Adjusted R-Squared & .7763 & .7806 \\
Durbin Watson & 1.9432 & 1.9627 \\
F test on $\triangle$ Adjusted R- & .6249 & \\
Squared & \\
\hline Note: Significant level at: ${ }^{*} \mathrm{p}<.10,{ }^{* *} \mathrm{p}<.05,{ }^{* * *} \mathrm{p}<.001 ;$ Depen- \\
dent Variable: Attitude toward adv.
\end{tabular}

The result of the first step regression analysis shows that the value of $\mathrm{R}^{2}$ adjusted $=$ 0.7763 , it indicates that the variance of sex appeal as much as $77.63 \%$, whereas the rest of the variance is explained by an external variable which is not in the model. The main effect of this research had positive relationship. This mean that the higher level of sex appeal, the higher consumer's attitude $(b=0.5006$, S.E $=0.0628)$ (Table 3). The value of $\mathrm{R}^{2}$ adjusted $=0.776360$, it indicates that the variance of sex appeal as 
much as $77.63 \%$, whereas the rest of the variance is explained by an external variable which is not in the model. This result is supported by the previous studies (Sengupta \& Dahl, 2008; Jones \& Reid, 2009; Black et al., 2010).

This finding is hopes to help marketer to develop strategies related to sex appeal. Marketer could use sexually appealing models to approach potential male consumers. Consumers would be interest in talking if the marketing agents have high level of sex appeal. It because the use of female in marketing especially in personal selling marketing is very essential in order to attract the attention of potential consumers.

There are lots of factors that shape the consumer's attitude towards the ads, one of them is sex appeal. The result of this study, it can be used for academic's purposes. It is expected to improve the understanding of consumer's attitude towards the ads.

The Relationships of sex appeal on consumers attitude towards the ads with Product Factor as Moderating Variable. Test of coefficient determinant is used to measure the goodness fit of the regression model. The value of Adjusted $\mathrm{R}$ Square is an overview of how much the independent variable able to explain the dependent variable on the regression model. As seen in Table 3, shown that second step regression model has an Adjusted R Square as much as .7895. It can be concluded that the independent variable able to explained the dependent variable as much as $78.9 \%$ whilst the remaining variance explained by another external variable which is not in the regression model.

Findings shown that the result of ARCH/ GARCH regression analysis is that the product factor as the moderating variable has significant value at 0.8896 . It means that product factor as the moderating variable has no influence to the consumers' attitude towards the ads as the dependent variable. Therefore, the second hypothesis is rejected $(b=0.0016, S . E=0.0118)$.

It is clear that sex appeal moderated by product factor didn't have any influence on the dependent variable. This phenomenon shows that the product promoted by the model that has sex appeal cannot effect on consumer's attitude. The result of this study contradicted with the result from the previous study (Black et al., 2010) which states that the product factor moderating the sex appeal on consumers' attitude towards the ads.

This finding if it is use for marketing purposes it need further research on the factors that shape the consumer's attitude. It also needs the correct adjustments of the female model with the product type that will be use and all the other factor should be put as considerations.

It is required further study in different setting and object along with stimulus with high level of difference. It is hopes to improve the theoretical concept that is hypothesized in this study. So it can be use both as academics purposes and practitioner purposes.

\section{CONCLUSION AND SUGGESTION}

The result of this research indicates that high degree of sex appeal was significantly affecting the consumers' attitude towards the ads. It answered the hypothesis presented at the beginning. The result of this study is supported by the previous researchers (Sengupta \& Dahl, 2008; Jones, 2009; Black et al., 2010), despite the differences in object observed. Meanwhile, sex appeal which is moderated by product factor does not have any effect on the consumers' attitude towards the ads. This result is contradicted by the previous research (Black et al., 2010).

The result of this study has theoretical implication for academic's purpose. It is based on the uniqueness that provides different perspective from the previous studies. This uniqueness can be seen from the research variables which were modeled and this research was adopted to set in Indonesia so that the result is trustworthy.

The result of this research can provide an insight to practitioners about consumers' attitude. Understanding sex appeal may provide huge advantages and benefits to marketer, which can be used to create strategies to get a positive attitude from the consumers. The use 
Aji Cahya Nusantara \& Budhi Haryanto/ The Influence of Sex Appeal on Consumers Attitude ...

of sex appeal needs to be careful, because the use of sex appeal for advertising combined with irreverent product will affect the consumers' attitude and will have no effective impact on the marketing strategies that are being developed.

Although there are many flaws in this research due to the inability of the research model to capture the phenomenon in all situation, but with the correct testing procedures is not expected to reduce the degree of trustworthy of the research.

\section{REFERENCES}

Anabila, P., Tagoe, C., \& Asare, S. (2015). Consumer Perception of Sex Appeal Advertising: a High Context Cultural Perspective. IUP Journal of Marketing Management, 14(4), 34-55.

Assael, H. (2004). Consumer Behavior, a strategic approach. (6th ed). New York: HoughtonMifflin.

Barnier, V. D., \& Valette-Florence, P. (2006). Provocative Sexually Appealing Advertisements: the Influence of Embarrassment on Attitude Towards the Ad. ACR Asia-Pacific Advances, 7(1), 215-222.

Black, I. R., Organ, G. C., \& Morton, P. (2010). The Effect of Personality on Response to Sexual Appeals. European Journal of Marketing, 44(9/10), 1453-1477.

Campbell, D. T., \& Stanley, J. C. (1966). Experimental and Quasi-Experimental Design for Research. Boston, Mass: Houghton Mifflin Company.

Courtney, A. E., \& Whipple, T. W. (1983). Sex Stereotyping in Advertising. Lexington, Mass. : Lexington Books.

Duncan, T. (2002). IMC: Using Advertising and Promotion to Build Brands. New York: McGrawHill.

Dudley, S. C. (1999). Consumer Attitudes toward Nudity in Advertising. Journal of Marketing Theory and Practice, 7(4), 89-96.

Elliott, R., Jones, A., Benfield, A., \& Barlow, M. (1995). Overt Sexuality in Advertising: a Discourse Analysis of Gender Responses. Journal of Consumer Policy, 18(2-3), 187-217.

Fishbein, M., \& Ajzen, I. (1975). Beliefs, Attitude, Intention and Behavior: an Introduction to Theory and Research. Washington D. C: AddisonWesley.
Haryanto, B., Nusantara, A. C., \& Budiman, S. (2015). How Sexuality in Elegance of Advertising and Congruency of Product Influence Brand Evaluation? (the Study of Consumer Behavior using an Experimental Design Approach). Mediterranean Journal of Social Sciences, 6(4), 118-129.

Jones, S. C., \& Reid, A. (2008). The Use of Female Sexuality in Australian Alcohol Advertising: Public Policy Implication of Young Adult's Reactions to Stereotypes. Journal of Public Affair, 12(4), 315-325.

LaTour, M. S., Pitts, R. E., \& Snook-Luther, D. C. (1990). Female Nudity, Arousal and Ad Response: an Experimental Investigation. Journal of Advertising, 19(4), 51-62.

LaTour, M. S., \& Henthorne, T. L. (1994). Ethical Judgments of Sexual Appeals in Print Advertising. Journal of Advertising, 23(3), 81-90.

Lee, S. M., Heflick, N. A., Park, J. W., Kim, H., Koo, J., \& Chun, S. (2017). When Sex doesn't Sell to Men: Mortality Salience, Disgust and the Appeal of Products and Advertisements Featuring Sexualized Women. Motivation and Emotion, 41(4), 478-491.

Liu, F., Li, J., \& Cheng, H. (2006). Sex Appeal Advertising: Gender Differences in Chinese Consumers Responses. Asia Pacific Journal of Marketing, 18(1), 19-28.

Lull, R. B., \& Bushman, B. J. (2015). Do Sex and Violence Sell? a Meta-Analytic Review of the Effects of Sexual and Violent Media and Ad Content on Memory, Attitudes and Buying Intentions. Psychological Bulletin, 141(5), 1022-1123.

Lutz, R. J. (1991). The Role of Attitude Theory in Marketing, in Perspectives in Consumer Behavior. Illinois, IL: Prentice Hall.

Malik, G. (2016). Impact of Sexual Content in Advertising on Purchasing Behaviour of Customers: an Empirical Analysis. ASBM Journal of Management, 9(1), 47-56.

Montgomery, D. C. (2001). Design and Analysis of Experiment, 5th Edition. Arizona State University: John Wiley \& Son, Inc.

Peterson, R. A., \& Kerin. R. A. (1977). The Female Role in Advertisement: Some Experimental Evidence. Journal of Marketing, 41, 59-63.

Reichert, T., \& Ramirez, A. (2000). Defining Sexually Oriented Appeals in Advertising: a Grounded Theory Investigation. Advances in Consumer Research, 27: 267-73. 
Reichert, T., Heckler, S. E., \& Jackson, S. (2001). The Effects of Sexual Social Marketing Appeals on Cognitive Processing and Persuasion. Journal of Advertising, 30(1), 13-27.

Reid, L. N., \& Soley, L. C. (1983). Decorative Models and the Readership of Magazine Ads. Journal Advertising Research, 23(2), 27-32.

Saunders, D. (1996). Sex in Advertising. Singapore: BT Batsford Ltd.

Sekaran, U., \& Bougie, R. (2013). Research Methods for Business. Chichester, England: John Wiley \& Sons Ltd.

Sengupta, J., \& Dahl, D. W. (2008). Gender-Related Reactions to Gratuitous Sex Appeals in Advertising. Journal of Consumer Psychology, 18(1), 62-78.

Soley, L., \& Kurzbard, G. (1986). Sex in Advertis- ing: a Comparison of 1964 and 1984 Magazine Advertisements. Journal of Advertising, 15(3), 46-64.

Steadman, M. (1969). How Sexy Illustrations Affect Brand Recall. Journal of Advertising Research, 9(1), 14-22.

Sugiarto, C., \& De Barnier, V. (2013). Sexually Appealing Ads Effectiveness on Indonesian Customers. European Journal of Business and Management, 5(9), 125-135.

Tabachnick, B., \& Fidell, L. (1997). Using Multivariate Statistic. London, England: Pearson Education.

Visetbhakdi, Arpavadee. (2011). The Effects of Sex Appeal Advertising on Thai Consumers' Emotional and Behavioral Responses. The AU Journal of Management, 9(1), 1-12. 